\title{
Relapsing piriformis syndrome treated with botulinum toxin injections
}

\author{
Paolo Ripellino, ${ }^{\oplus}$ Alessandro Cianfoni, ${ }^{2}$ Mikael Gian Andrea Izzo, ${ }^{1}$ Claudio Gobbi ${ }^{1}$
}

${ }^{1}$ Neurology, Neurocenter of Southern Switzerland, Lugano, Switzerland

${ }^{2}$ Neuroradiology, Neurocenter of Southern Switzerland, Lugano, Switzerland

\section{Correspondence to Dr Claudio Gobbi, claudio.gobbi@unibas.ch}

Accepted 28 June 2019

\section{DESCRIPTION}

Piriformis syndrome is due to entrapment of the sciatic nerve by the piriformis muscle. Buttock pain is exacerbated by activities that promote internal rotation of the hip, as the muscle promotes external hip rotation. This entity is unusual, sometimes even controversial, and is difficult to diagnose. Piriformis syndrome should be suspected when more common conditions, such as S1 radiculopathy, sacroiliitis, facet arthropathy and lumbar disk disease, have been excluded by imaging. ${ }^{1}$ Moreover, MRI of the pelvic girdle is extremely helpful to assist the diagnosis, because it can show structural changes in the muscle, ${ }^{2}$ as in the present case.

A 35-year-old man started suffering from right buttock and pelvic pain and in the right leg without any history of trauma. Clinical examination was significant for positive Freiberg's, Pace's, Beatty's and flexion, adduction, internal rotation (FAIR) manoeuvres, suggesting piriformis syndrome. ${ }^{1}$ Electrodiagnostic studies ruled out lumbar radiculopathy or plexopathy. MRI demonstrated asymmetric hypertrophy of the right piriformis muscle (figure 1A) and was unremarkable in the lumbar spine. ${ }^{2}$ Conservative treatment with anti-inflammatory analgesic therapy, physical therapy and pregabalin $300 \mathrm{mg} /$ day for 4 months did not lead to pain improvement. We treated the patient with three CT-guided botulinum toxin A injections (100 UI for the first injection and 50 UI for the others, in $2 \mathrm{~mL}$ saline solution, injected in equally divided

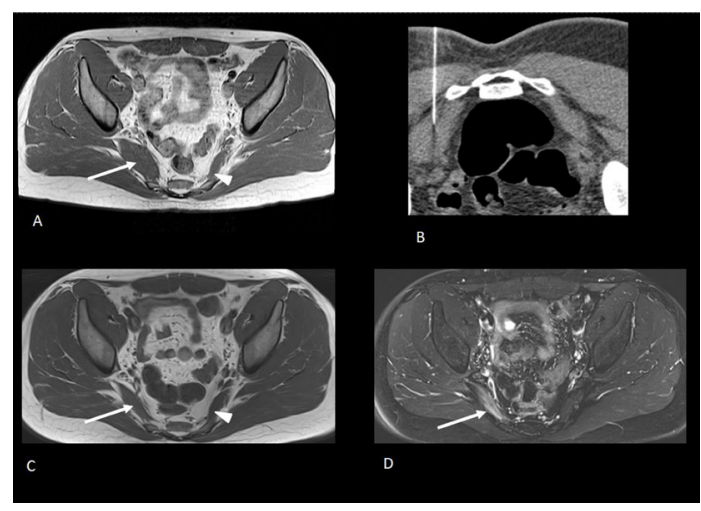

Figure 1 (A) MRI at diagnosis. Axial T1-w images show size asymmetry of piriformis muscles, with right (white arrow) much thicker than left (white arrowhead). (B) CTguided botulinum toxin injection in the right piriformis muscle. (C, D) MRI 5 months after the first injection. Axial T1-w images (C) show amyotrophy of the right piriformis muscle (white arrow), while axial T2-w fat sat images (D) show muscle denervation.



Figure 2 MRI at relapse (3 years later). Axial T1-w images show recurrent asymmetric hypertrophy of the right piriformis muscle (white arrow).

doses into two locations of the muscle) within the first year (figure 1B), causing selective amyotrophy (figure 1C) and denervation (figure 1D) of the right piriformis muscle, with dramatic pain improvement. ${ }^{3}$ Three years later, the same pain relapsed together with reappearance of asymmetric right piriformis muscle hypertrophy (figure 2 ). We therefore repeated botulinum toxin injection in the right piriformis, obtaining sustained (more than 24 months) pain remission. ${ }^{3}$

The prolonged follow-up in this case allowed us to find a direct correlation between piriformis muscle hypertrophy and clinical symptoms. Muscle

\section{Patient's perspective}

Physiotherapy and painkillers were not effective and I was desperate. I could not sit or work anymore and my quality of life was poor. Three weeks after the first botulinum toxin infiltration I felt an immediate and long lasting improvement in symptoms, so we repeated the injections and I felt an improvement after each intervention. After 2 years the pain in the buttock reappeared and I asked for another injection, that was again successful in controlling my pain. I would suggest the use of botulinum toxin injection to other patients with this rare disease.

\section{Learning points}

Piriformis syndrome can be caused by an asymmetric hypertrophy of the piriformis muscle and MRI seems helpful for diagnosis.

- In case of piriformis muscle hypertrophy, injection of botulinum toxin may be efficacious.

- Piriformis syndrome may relapse after several years, but still respond to repeated botulinum toxin injections. 
MRI can be used to identify muscle hypertrophy, as a target for botulinum toxin injection.

Contributors PR, AC, MGAI and CG collected clinical data and followed-up the patient. PR wrote the manuscript. PR, AC, MGAI and CG revised the manuscript and edited it for intellectual content.

Funding The authors have not declared a specific grant for this research from any funding agency in the public, commercial or not-for-profit sectors.

Competing interests None declared.
Patient consent for publication Obtained.

Provenance and peer review Not commissioned; externally peer reviewed.

\section{REFERENCES}

1 Kirschner JS, Foye PM, Cole JL. Piriformis syndrome, diagnosis and treatment. Muscle Nerve 2009;40:10-18.

2 Lee EY, Margherita AJ, Gierada DS, et al. MRI of Piriformis syndrome. AJR Am Roentgenol 2004;183:63-4.

3 Jabbari B, Machado D. Treatment of refractory pain with botulinum toxins--an evidencebased review. Pain Med 2011;12:1594-606.

Copyright 2019 BMJ Publishing Group. All rights reserved. For permission to reuse any of this content visit

https://www.bmj.com/company/products-services/rights-and-licensing/permissions/

BMJ Case Report Fellows may re-use this article for personal use and teaching without any further permission.

Become a Fellow of BMJ Case Reports today and you can:

- Submit as many cases as you like

- Enjoy fast sympathetic peer review and rapid publication of accepted articles

Access all the published articles

Re-use any of the published material for personal use and teaching without further permission

\section{Customer Service}

If you have any further queries about your subscription, please contact our customer services team on +44 (0) 2071111105 or via email at support@bmj.com.

Visit casereports.bmj.com for more articles like this and to become a Fellow 